\title{
Customer Engagement through Using Anime Stylized Advertisement
}

The paper analyses the ways how to engage more customers using anime stylized advertisement and provides new insights on it. The data was obtained through the scientific literature analysis and qualitative research. The results were provided based on in-depth interviews.

Keywords: customer engagement, factors influence on customer engagement, advertisement, anime.

Straipsnyje analizuojami būdai, kaip įtraukti daugiau vartotojų naudojant animè stilizuotą reklamą ir pasiūlyti naujų ižžlgų jai naudoti. Duomenys buvo renkami analizuojant mokslinę literatūrą ir atliekant kokybinị tyrimą. Tyrimo rezultatai gauti giluminio interviu metodu.

Raktiniai žodžiai: vartotojų ịsitraukimas, veiksniai, turintys ịtakos vartotojų ịsitraukimui, reklama, animè.

\section{Introduction}

In the contemporary world, marketers fight for customers' attention every second. From year to year it becomes more difficult and demands new ways of customer engagement. The main reason is that modern customers look for uniqueness, and for products and services, which stand out from the huge amount of offers. Some of these ways have common features all over the globe, others depend on the cultural background of target audience. In every country, exist unique trends and preferences, which rarely go outside this exact country. One of such trends is Japanese anime-stylized advertisement, which is widely used in Japanese companies' pro- motional campaigns. It is caused by the fact that during the 100-year history of the anime existing, it has evolved to the subculture in Japan. In 2016, the part of the permanent anime viewers in Japan was $32 \%$ of the population, that is equivalent to 31,24 million people (Gzbrain Inc., 2017).

Moreover, over the past two decades anime has got traction outside Japan, including Europe and the USA. According to the Association of Japanese Animation (AJA) statistics of the year 2017, in 2016 Japan's profit from selling anime abroad was 767.6 million $¥$ (AJA, 2017, p. 6). These figures show the rate of involvement in the anime culture in the today's world. However, despite of this fact, marketers from other countries still avoid using such

\footnotetext{
Nina KLEBANSKAJA - doctor of social sciences, assoc. professor of marketing at the Faculty of Economics and Management, Vytautas Magnus University, Lithuania. Address: K. Donelaičio str. 58, 44248, Kaunas, Lithuania. E-mail: nina.klebanskaja@vdu.lt

Olena ANDRIUKHANOVA - Master student at the Faculty of Economics and Management, Vytautas Magnus University, Lithuania. Address: K. Donelaičio str. 58, 44248, Kaunas, Lithuania. E-mail: olena.andriukhanova@vdu.lt
} 
specific ways of customer engagement. In the authors' view, it is caused by the lack of research on the issue how narrow-focused tendencies could influence customers from other countries. It means that the question which is raised in this paper has relevance in the modern evolution of customer engagement and could be useful for further research in this field.

Therefore, the scientific problem analysed in this paper is introduced in the question form: How to engage more customers using anime stylized advertisement?

Consequently, the object of research is customer engagement. The aim of the paper is to identify factors, which are important in anime style advertising in order to engage more customers.

The objectives set to achieve the aim of this paper are:

1. To distinguish the most effective ways how to engage more customers using anime stylized advertisement from theoretical point of view.

2. To empirically test the theoretically distinguished ways how to engage more customers using anime stylized advertisement.

3. To provide practical insights of the theoretically distinguished ways on how to engage more customers using anime stylized advertisement.

\section{Literature analysis: theoretical insights of customer engagement}

\subsection{Customer engagement}

The term 'engagement' is used in different fields as social psychology (Achtherberg et al., 2003), sociology, organiza- tional studies (Greenwood, 2007; Saks, 2006), educational researches (Bryson and Hand, 2007; London, Downey, and Mace, 2007), cognitive science, politics, etc. In every case, 'engagement' is unidimensional (emotional, cognitive, behavioural) or multidimensional (cognitive/ emotional, cognitive/behavioural; cognitive/emotional/behavioural) (Avnet and Higgins, 2006a; Brodie et al., 2011; Hollebeek, Glynn, Brodie, 2014).

In marketing, this term is supposed to be a new one. The 'customer' was included on it, and as a result we have 'customer engagement'. There exist a variety of definitions, however, the most extensive one is as follows (Brodie et al., 2011; Haurum, 2018; Leeflang, 2011):

"Customer engagement (CE) is a psychological state that occurs by virtue of interactive, co-creative customer experiences with a focal agent/object (e.g., a brand) in focal service relationships. It occurs under a specific set of context-dependent conditions generating differing CE levels; and exists as a dynamic, iterative process within service relationships that co-create value. $\mathrm{CE}$ plays a central role in a nomological network governing service relationships in which other relational concepts (e.g., involvement, loyalty) are antecedents and/ or consequences in iterative CE processes. It is a multidimensional concept subject to a context- and/or stakeholder-specific expression of relevant cognitive, emotional and/or behavioral dimensions" (p. 260).

Discussing about the meaning of 'customer engagement' Roderick J. Brodie (2011) described that after content analysis of more than 50 articles, $2 / 3$ of them were about business-to-customer (B2C) relationships, and $1 / 3$ about business-tobusiness (B2B) relationships. In the $\mathrm{B} 2 \mathrm{~B}$ 
relationships 'engagement' described process, cocreation, solutions of service exchange. In the $\mathrm{B} 2 \mathrm{C}$ it also was mostly about customer and/or brand experience, creativity, learning, emotions, collaboration and/or (brand) community interactions.

Therefore, customer engagement is used for creating rational and emotional bonds between customer and brand, what at the same time has influence on development of brand loyalty (Avnet and Higgins 2006a, 2006b; Bowden, 2009; Pham and Avnet, 2009; Schau, Muñiz, and Arnould, 2009). It is possible to reach using targeting, segmentation and marketing mix tools as pricing, placing, for customer engagement strategy branding, pricing, placing and promotion. Every of these ways of engagement has its own features and hidden techniques.

Content marketing is one of the most prominent modern marketing concepts. One of the pillars of content marketing is customer engagement. According S. U. Kucuk and S. Krishnamurthy (2007, p. 49) "content marketing attracts potential consumers and increases their engagement and empowerment". Different types of content have different impact on customer engagement. Be more concrete, the question is what is relations between different type of appeals and customer engagement? Sheehan and Morrison (2009) point that the creativity of the content is key success factor encouraging consumers engagement in order to produce desired brand outcomes. It can be achieved using social as well as traditional media. Advertising is one of it.

To make an advertising influence on customers and 'engage' them, it must have an impact on their emotions, memories and experience (Calder, Malthouse,
Schaedel, 2009). In other words, 'memories' and 'experience' consist of customers' belief about value and benefits which they can get from the brand or particular product. One of the aims of advertising is causing the inner wishes, associations and memories which will make customer unconsciously want to experience it one more time, and as a result to consume (van Praet, 2014). What means every advertising should be individualized for the certain customers segment or even personally for every customer (Hite et al., 1995), in the case the 'engagement' is a main goal.

Different types of advertising involve on the consumers behaviour in different ways. In this research will be performed only visual way, and particularly the using of video content, which is represented as well on the TV as in the Internet. Both sources are used depending on the target audience.

Moreover, the view and style of these videos are culturally sensitive and differ from country to country. These features demand the deep analysis of marketing environment, and can be done by taking in account religion, language, educational level, aesthetics, social organization etc. (Chee and Harris, 1998). Such analysis provides marketers with necessary information which will be used for creation the suitable advertising for certain target audience of certain country, that influences on the customer engagement. It may be researched on the case with the Japanese anime stylized advertisement.

\section{2. 'Anime' - Japanese animation}

'Anime' originally is the Japanese animation, which is characterized mostly by dynamic characters, fantastic themes and 
colourful graphics. The world 'Anime' was created by Japanese as an abbreviated pronunciation of 'animation. The first commercial anime was produced in 1917 and the further producing was expanded rapidly. Later, in 1960s, anime got its own characteristic art style from Osamu Tezuka's works, which was spread in to late 20th century (MacWilliams, 2008). At that time, when from decade to decade the main features of anime stayed the same, others changed completely.

There are a lot of different genres which are aimed at the specific target audience differentiated by age, gender, and personal preferences. Some of these genres are common for the filming area $(\mathrm{Ne}-$ witz, 1994), as romance, horror, drama and science-fiction, others unique and exist only in Japanese anime, as 'shoujo' (target audience is young girls and women), 'shounen' (target audience is young boys and men), 'josei' (target audience is adult women) etc. (Norrism, 2009).
Nowadays 'Anime' is the modern worldwide phenomena that has affection as on the West as on the East. It reflects the Japanese culture and has the high acceptance and involvement in it by Japanese people and foreigners (Napier, 2005). Popular anime characters can be seen all over Japan on T-shirts, toys, accessories and stationery. Also, different companies use anime-style characters to attract young people to their brand (Xie Qing-guo, Cao Yan-hui, 2011). Based on these facts Japanese marketers decided to use the anime style and anime characters in promotion companies of different companies as the new method of customer engagement.

To provide the clear understanding and vision of the reasons that make Anime widely recognized all over the world, there were distinguished main features that influence on people dedication into this unique kind of animation (Table 1).

Taking into the account importance of content in customer engagement, anime

Table 1. Features that influence on people dedication into Anime

\begin{tabular}{|c|c|c|c|}
\hline & Feature & \multicolumn{2}{|r|}{ Description } \\
\hline \multirow[b]{2}{*}{1} & & Complex plot & Complex characters \\
\hline & Complexity & $\begin{array}{l}\text { Anime plots have tendency to be } \\
\text { more complex that plots of regular } \\
\text { animation projects. For instance, the } \\
\text { anime plot typically develops over } \\
\text { the of course of dozens of episodes, } \\
\text { and the one anime can have more } \\
\text { than } 50 \text { episodes. }\end{array}$ & $\begin{array}{l}\text { Anime characters are complex themselves. It could } \\
\text { be seen from their appearance, that has lots of small } \\
\text { features as colour and shape of hair, eyes, etc., that } \\
\text { influence on character's behaviour and personality. } \\
\text { In addition, the fact that anime often has more than } \\
50 \text { episodes, character's personality develops during } \\
\text { all storyline by interaction with other characters. }\end{array}$ \\
\hline 2 & Adult focus & \multicolumn{2}{|c|}{$\begin{array}{l}\text { Anime, as any animation, is often supposed to be made for children. However, despite the } \\
\text { animation style, the nature of the anime plots, which often focused on the adult themes, is } \\
\text { often best understood and enjoyed by adults instead of children. It refers to the complexity of } \\
\text { plot, that viewers should be able both to understand and engage with during all the storyline. }\end{array}$} \\
\hline 3 & $\begin{array}{l}\text { Exaggerated } \\
\text { physical } \\
\text { features }\end{array}$ & \multicolumn{2}{|c|}{$\begin{array}{l}\text { Comparing with propositional bodies of anime characters, their facial expressions are usu- } \\
\text { ally exaggerated and brightly coloured. The most typical exaggeration is the characters' eyes } \\
\text { that can take up to half of the face. Through these large eyes the animator can express the } \\
\text { characters' emotions. In addition to eyes, characters often have wild, unnaturally coloured } \\
\text { hair. The reason is reflection of inner world of character through drawing unreal appearance. }\end{array}$} \\
\hline
\end{tabular}


style advertising can be used like emotionally attractive and engaging content for different audiences.

\section{Methodology}

\subsection{Research method}

The aim of this research paper is to theoretically test the distinguished ways to engage more customers in using anime stylized advertisement. This study should be treated as an exploratory research and as the first stage of more comprehensive research. So, this type of research does not intend to offer final and conclusive solutions to existing problems. It aims to provide an understanding of human behaviour, emotion, attitudes, and experiences (Tong et al., 2012). In many cases exploratory research is based on qualitative methods. According to D. R. Cooper and P. S. Schindler (2006) in-depth interview is useful in exploratory research. This method has been chosen, because of the necessity to understand the inner expectations of potential consumers and to identify the main factors which effect customer engagement, especially through the anime stylized advertisement. The tradition of qualitative research suggests using research questions instead of hypothesis usually needed in qualitative research. Research questions may not be very specific due to lack of current research on the topic of interest. It is valid in this case.

During the literature analysis there have been distinguished the following research questions:

1. Does Anime reflect cultural features that influence customer engagement?

2. How is Anime specified for different target audiences to influence customer engagement?

3. What are unique features of Anime that influence customer engagement?

\subsection{Research design}

The number of respondents is 6 (Table 2). M. Q. Patton (2002) explains "there are no rules for sample size in qualitative inquiry. Sample size depends on what you want to know, the purpose of the inquiry, what's at stake, what will be useful, what will have credibility, and what can be done with available time and resources (pp. 242243). In this particular study, 6 respondents were selected.

Regarding the requirements which the respondents had to meet, there was the only one. They had to be no older than

\section{Table 2. Selected respondents for interview}

\begin{tabular}{|c|c|c|c|c|}
\hline Respondent & Nationality & Age & Education & Involvement into the 'Anime' \\
\hline Leyli & Azerbaijan & 17 & Bachelor student & Interested a lot \\
\hline Julia & Ukraine & 21 & Bachelor student & Interested \\
\hline Daria & Ukraine & 16 & High school student & Not interested \\
\hline Iliya & Russia & 22 & Bachelor & Interested \\
\hline Zhuldyz & Kazakhstan & 25 & Master student & Not interested \\
\hline Mariia & Ukraine & 21 & Bachelor & Not interested \\
\hline
\end{tabular}


30 years of age, because of the specific aspects of spreading anime outside of Japan. The other requirements were absent. It was due to the variety of age and gender target audience segment which exists in the anime industry. This fact shows us that the respondents as well as the target audience of investigated advertisement type could have no common features and be the target audience.

During this research the respondent will answer the following questions (Table 3):

\section{Results}

\subsection{Data analysis}

During the interviews the respondents answered on the proposed 8 questions. The analysis of answers is presented by means of comparison analysing all the answers within the first question, one by one.
1. Usually, what are the first thing that you notice in a video advertising and why?

Mostly all respondents concluded that the visual part of an advertisement is the first thing which attract their attention. Five of them mentioned such criteria as 'colourful', 'brightness', 'pleasant appearance', and only the one respondent, Daria, mentioned 'human'.

These answers show us that the animation and visual part are the most important features in video advertisement as the factors which influence on customer engagement.

2. Do you notice the cultural features of your or foreign country and what influence it has on your attitude to this certain advertisement?

All the respondents noted 'Yes, I notice, but mentioned only obvious features. Three of the respondents added that these features had no influence on their attitude to the advertisement and to a product. Two

Table 3. The questions for in-depth interviews

\begin{tabular}{|c|l|l|}
\hline 1. & \multicolumn{1}{|c|}{ Research questions } & \multicolumn{1}{c|}{ Questions } \\
\hline $\begin{array}{l}\text { that Anime reflect cultural features } \\
\text { engagement? }\end{array}$ & $\begin{array}{l}\text { Usually what the first thing do you notice in a video advertising } \\
\text { and why? } \\
\text { Do you notice the cultural features of your or foreign country and } \\
\text { how is it influence on your attitude to this certain advertisement? } \\
\text { Does it important to see the reflection of your culture and why? } \\
\text { What will you think about the advertisement which are made in } \\
\text { the anime style but has the features of your culture? }\end{array}$ \\
\hline 2. & $\begin{array}{l}\text { How is Anime specified for different } \\
\text { target audiences that influence on cus- } \\
\text { tomer engagement? }\end{array}$ & $\begin{array}{l}\text { If you watch the advertisement of the product/ service which is } \\
\text { well-known by you, will you be interested in this product? } \\
\text { If the unknown product is advertised, will you continue to watch } \\
\text { advertisement till the end and why? } \\
\text { What if both well-known and unknown products have the anime } \\
\text { stylized advertisement, will you be more interested in presented } \\
\text { products? }\end{array}$ \\
\hline 3. & $\begin{array}{l}\text { What unique features has Anime that } \\
\text { influence customer engagement? } \\
\text { Anime has unique features that have } \\
\text { influence on customer engagement }\end{array}$ & $\begin{array}{l}\text { Can you provide some reasons why you watch the anime stylized } \\
\text { advertisement? Also, name the reasons in case of the negative } \\
\text { answer. }\end{array}$ \\
\hline
\end{tabular}


of them (Leyli, Julia) said that the cultural features will be perceiver positively about their attitude to the advertisement, not to a product. And only 1 respondent, Daria, mentioned that if she sees the features of culture she doesn't like, her attitude to an advertisement will be negative.

The provided answers show that the cultural features in an advertisement will be have no results on the customer engagement, or the only few per cents of viewers will be engaged by this mean.

\section{Is it important to see the reflection of your culture and why?}

All respondents were single-minded and answered that the reflection of their culture has no importance for them, because they are not patriots.

This answer can be interpreted as the fact, that the culture features are equal to the feeling of patriotism for customers, and that in the modern world such things as patriotism and original culture have no influence on customer engagement.

4. What do you think about the advertisement which is made in the anime style but has the features of your culture and which impression it will make on you?

Four of respondents answered that this type of advertisement will make the positive impression on them because it looks 'modern' and 'unique. The last two respondents (Julia, Daria) answered that such advertisement will cause the negative feeling, because of the 'absurdity' of this combination of cultures aspects in one advertisement.

Collected answers shows that using of anime stylized advertisement abroad the Japan will engage customers by its uniqueness and modernity. However, marketers should be careful about adding to such advertisement the elements that reflect the culture which has nothing common with Japanese one, because it could cause the negative feeling of 'absurdity'.

\section{If you watch the advertisement of} the product/service which is well-known by you, will you be interested in this product more?

Only two respondents gave the answer 'yes' and explained it as "that means the product has new features, which will be interesting for me' (Leyli) and 'that means the product is in demand' (Zhuldyz). The other respondents said that an advertisement will not influence on their engagement it the product, because they already use it.

These data display the tendency of ignoring the well-known product advertisement despite on its style and other additional characteristics and ways which were used in creation of this advertisement. It will not be successful in the customer engagement purpose.

6. If the unknown product is advertised, will you continue to watch advertisement till the end and why?

All respondents said that will watch an advertisement till the end, but on different reasons. Three of them called the 'product' as the main reason. The other two suppose that the plot of advertisement is the most important part of advertisement. And only the one (Iliya) called both reasons.

Analysing of these answers demonstrate that for customers the product which is advertised more important than the way, how it was done. That means, the advertisement which has detailed plot could engage customers, but only if they are interested in product. 
7. What if both well-known and unknown products have the anime stylized advertisement, will you be more interested in presented products?

All respondents, excepting one (Zhuldyz), answered that the advertisement of any product produced in anime style will not increase their interest to the advertised product in general. Two of them mentioned the additional reasons as 'I will search additional information in any case' (Iliya) and 'If it is advertisings of some serious product/service as bank or insurance company, it will cause negative feeling by its dissonance between appearance and meaning' (Daria). The respondent, whose answered 'yes'(Zhuldyz) explained, that such type of advertisement will be interesting for her because of natural curiosity 'how it will looks', however she will be interested in a product, only in an advertisement.

Provided answers shows that for customers the product is on the first place in advertisement, and only then goes the visual part of it. This fact means that there is no difference is in advertisement used anime style or other one, without value product they will not be engaged.

8. Can you provide some reasons why you watch the anime stylized advertisement? Also, name the reasons in case of the negative answer.

The respondents distinguished the following four reasons, why they may watch the anime stylized advertisement (Table 4):

The analysis of provided answers shows that the 'Animation style' is the most important factor in watching the anime stylized advertisement. Moreover, this reason is common for all levels of involvement into the 'Anime' as a phenomenon. The other reasons as 'Product', 'Plot' and 'Famous character' also have the influence on customers engagement, but not as powerful as 'Animation style'.

\subsection{Conclusions}

After the analysis of collected data there have been formulated the following questions for further research:

1. Does Anime reflect cultural features that have influence on customer engagement?

2. How is Anime specified for different target audiences to have influence on customer engagement?

3. What unique features has Anime that influence customer engagement?

To conclude the performed research, the authors can state that seeking to increase customer engagement by means of video advertisement, the product which is advertised have to meet customers' interests. However, if marketers use the anime stylized advertisement, the attention of

Table 4 . The reasons provided by respondents why they watch anime stylized advertisement

\begin{tabular}{|c|c|c|}
\hline Reason & Number of respondents & Names \\
\hline Animation style & 4 & Leyli, Julia, Iliya, Zhuldyz \\
\hline Product & 2 & Leyli, Daria \\
\hline Plot & 3 & Iliya, Zhuldyz, Maria \\
\hline Famous character & 2 & Iliya, Maria \\
\hline
\end{tabular}


customers is caught by the visual part of advertisement as 'Animation style. Then they pay attention to the 'Plot' of the advertisement, and only after these two factors follows 'Product'. But at the same time interest in the product is less than in the advertisement as it is.
This tendency could be useful in advertising of different products and services, depending on the aims which are set, i.e. whether the aim is to concentrate customer's attention directly to the product or to increase the awareness of a company/brand.

\section{References}

1. Achtherberg, W., Pot, A. M., Kerkstra, A., Ooms, M., Muller, M., Ribbe, M. (2003). The Effect of Depression on Social Engagement in Newly Admitted Dutch Nursing Home Residents // The Gerontologist. Vol. 43, No. 2, pp. 213-218. doi: 10.1093/geront/43.2.213

2. Avnet, T., Higgins, E. T. (2006a). How Regulatory Fit Affects Value in Consumer Choices and Opinions // Journal of Marketing Research. Vol. 43, No. 1, pp. 1-10.

3. Avnet, T., Higgins, E. T. (2006b). Response to Comments on "How Regulatory Fit Affects Value in Consumer Choices and Opinions" // Journal of Marketing Research. Vol. 43, No. 1, pp. 24-7.

4. Bowden, J. L. H. (2009). The Process of Customer Engagement: A Conceptual Framework // Journal of Marketing Theory and Practice. Vol. 17, No. 1, pp. 63-74. doi: 10.2753/ MTP1069-6679170105.

5. Brodie, R., Hollebeek, L., Juric, B., Ilic, A. (2011). Customer Engagement: Conceptual domain, fundamental propositions, and implications for research // Journal of Service Research. Vol. 14, No. 3, pp. 252-271. doi: $10.1177 / 1094670511411703$

6. Bryson, C., Len, H. (2007). The Role of Engagement in Inspiring Teaching and Learning // Innovations in Education and Teaching International. Vol. 44, No. 4, pp. 349-362. doi: 10.1080/14703290701602748

7. Calder, B. J., Malthouse, E. C., Schaedel, U. (2009). An Experimental Study of the Relationship between Online Engagement and Advertising Effectiveness // Journal of Interactive Marketing. Vol. 23, No. 4, pp. 321331. doi: 10.1016/j.intmar.2009.07.002

8. Chee, C., Harris, R. (1998). Global Marketing Strategy. - London: Financial Times Professional publishing.
9. Cooper, D. R., Schindler, P. S. (2003). Business Research Methods. 8th ed. - Boston: McGrawHill Irwin.

10. Eberle, K. (2015). Animation Styles: What Makes Anime Unique. Internet access: http:// showmetheanimation.com/features/animationstyles-what-makes-anime-unique/ [accessed October 20, 2018].

11. Greenwood, M. (2007). Stakeholder Engagement: Beyond the Myth of Corporate Responsibility // Journal of Business Ethics. Vol. 74, No, 4, pp. 315-327.

12. Gzbrain Inc. (2017). 日本におけるアニメ視 聴の概況. Internet access: https://www.f-ism. net/report/anime_mkt_2017_sammary.html [accessed October 12, 2018].

13. Haurum, H. (2018). Customer Engagement Behavior in the context of Continuous Service Relationships. - $\mathrm{PhD}$ diss., Copenhagen Business School.

14. Hite, K.C., Ciciora, W. S., Alison, T., Beauregard, R. G. (1995). System and Method for Delivering Targeted Advertisements to Consumers Using Direct Commands // United States Patent. Vol. 19.

15. Hollebeek L. D., Glynn, M. S., Brodie, R. J. (2014). Consumer Brand Engagement in Social Media: Conceptualization, Scale Development and Validation // Journal of Interactive Marketing. Vol. 28, No. 2, pp. 149-165. doi: 10.1016/j.intmar.2013.12.002.

16. Hope, S. J., Muñiz, A. M. Jr, Arnould, E. J. (2009). How Brand Communities Create Value // Journal of Marketing. Vol. 73, No. 5, pp. 30-51.

17. Kucuk, S. U., Krishnamurthy, S. (2007). An Analysis of Consumer Power on the Internet // Technovation. Vol. 27, No. 1, pp. 47-56. doi: 10.1016/j.technovation.2006.05.002 
18. Leeflang, P. (2011). Paving the Way for Distinguished Marketing // International Journal of Research in Marketing. Vol. 28, No. 2, pp. 76-88. doi: 10.1016/j.ijresmar.2011.02.004

19. London B., Downey, G., Mace, S. (2007). Psychological Theories of Educational Engagement: A Multi-method Approach to Studying Individual Engagement and Institutional Change // Vanderbilt Law Review. Vol. 60, No. 2, pp. 455-481.

20. MacWilliams, M. W. (2008). Japanese Visual Culture: Explorations in the World of Manga and Anime. - New York, NY: Routledge.

21. Napier J. S. (2005). Anime from Akira to Howl's Moving Castle. - New York, NY: Palgrave Macmillan.

22. Newitz, A. (1994). Anime Otaku: Japanese Animation Fans Outside Japan // Bad Subjects. Vol. 13, April.

23. Norrism, C. J. (2009). Manga, Anime and Visual Art Culture / In the Cambridge Companion to Modern Japanese Culture (Cambridge Companions to Culture), ed. Y. Sugimoto, $\left(1^{\text {st }}\right.$ ed). - Cambridge, UK: Cambridge University Press, pp. 236-260.

24. Patton, M. Q. (2002). Qualitative Research \& Evaluation Methods. - Thousand Oaks, CA: Sage Publications, Inc.

25. Pham, M. T., Avnet, T. (2009). Rethinking Regulatory Engagement Theory // Journal of Consumer Psychology. Vol. 19, No. 2, pp. 11523. doi: $10.1016 /$ j.jcps.2009.02.003
26. Saks, M. A. (2006). Antecedents and Consequences of Employee Engagement // Journal of Managerial Psychology. Vol. 21, No. 7, pp. 600-619. doi: 10.1108/02683940610690169

27. Sheehan, K. B., Morrison, D. K. (2009). The Creativity Challenge: Media Confluence and Its Effects on the Evolving Advertising Industry // Journal of Interactive Advertising. Vol. 9, No. 2, pp. 40-43. doi: 10.1080/15252019.2009.10722154

28. The Association of Japanese Animation. (2017). Anime Industry Report 2017 Summary (Revision) [Data file]. Internet access: http:// aja.gr.jp/english/japan-anime-data [accessed October 12, 2018].

29. Tong, A., Flemming, K., McInnes, Oliver, E. S., Craig, J. (2012). Enhancing Transparency in Reporting the Synthesis of Qualitative Research: ENTREQ // BMC Medical Research Methodology. Vol. 12, No. 1, pp. 181. doi: 10.1186/1471-2288-12-181

30. Van Praet, D. (2014). Unconscious Branding: How Neuroscience Can Empower (and Inspire) Marketing. - New York, NY: Palgrave Macmillan.

31. Xie Qing-guo, Cao Yan-hui. (2011). Cartoon Commercials on the Rise - On the Prospect of the Cartoon Commercials Developing in Viral Spreading Speed // Journal of Xuzhou Institute of Technology, Social Sciences Ed.

The paper submitted: November 10, 2018

Prepared for publication: December 20, 2018

Nina KLEBANSKAJA, Olena ANDRIUKHANOVA

\section{VARTOTOJỤ İITRAUKIMO DIDINIMAS NAUDOJANT ANIMĖ STILIAUS REKLAMA}

\section{$\mathrm{S}$ a n t r a u a}

Straipsnio tikslas - nustatyti veiksnius, kurie svarbūs animè stiliaus reklamai, siekiant didinti vartotojų ịsitraukimą. Straipsnị sudaro mokslinès literatūros analizè vartotojų i̇sitraukimo klausimais ir empirinis kokybinis tyrimas. Straipsnio pabaigoje pateikiamos išvados.

Straipsnyje analizuojama mokslinè literatūra vartotojų įsitraukimo, jo svarbos reklamos kampanijose klausimais ir būdai, kurie naudojami, siekiant didesnio vartotojų įsitraukimo, akcentuojant vaizdo reklamų naudojimą. Taip pat aptariamas anime kaip Japonijos fenomenas, kurio populiarumas pasaulyje vis labiau auga. Be to, straipsnyje pateikiami animè stiliaus reklamos bruožai, kuriuos vertina vartotojai. Animé populiarumas Japonijoje paskatino Japonijos rinkodaros specialistus naudoti animè stiliaus reklamas, siekiant sulaukti daugiau dèmesio 
reklamoms ir pasiekti didesnị vartotojų ịsitraukimą. Š tendencija kartu su animé populiarumo augimu plinta ir už Japonijos ribų.

Empirinis tyrimas pateikia giluminių interviu, kurie buvo atlikti su 6 respondentais, rezultatus. Visi respondentai nèra Japonijos piliečiai ir yra ne vyresni kaip 30 metų. Jiems buvo pasiūlyta atsakyti ị 8 atviruosius klausimus apie kultūrinių aspektų poveiki, siužetą, charakterius ir reklamų stilių bei kaip visa tai veikia vartotojų i̇sitraukimą. Analizuojant interviu būdu gautą informaciją pastebèta, kad kultūrinis aspektas neturi įtakos vartotojų ísitraukimui. $\mathrm{O}$ siužetas ir animacijos stilius yra tie veiksniai, kurie veikia vartotojų isitraukimą.
Tyrimo išvadose akcentuojama, kad vaizdo formatas kartu su jau ịvardytais siužetu, animè reklamos stiliumi, personažais teigiamai veikia vartotojų ịsitraukimą. Vaizdo siužetas sulaukè daugiau dèmesio negu produktas, kuris buvo reklamuojamas. Visa tai rinkodaros specialistams svarbu ịvertinti, kuriant modernias reklamos kampanijas. Akivaizdu, kad animè stiliaus reklamų naudojimas priklauso nuo reklamos kampanijos tikslų - ar siekiama atkreipti vartotojų demesi i reklamuojamą produktą, ar tikslas yra didinti vartotojų prekès ženklo suvokimą. Remdamasi tuo, kompanija gali kryptingai siekti norimo animé stiliaus reklamos efekto. 